\title{
Comparison of refined and non-refined wastewater effect on wheat seed germination and growth under drought
}

\author{
Hassan Heidari ${ }^{* *}$ and Saman Moradi ${ }^{1}$ \\ 'Department of Agronomy and Plant Breeding, Faculty of Agricultural Science and Engineering, Razi University, Kermanshah, Iran
}

\begin{abstract}
Wastewater has attracted special attention as a possible source of irrigation. The present study aimed to compare the effect of refined and non-refined wastewater on wheat seed germination and growth under induced drought conditions in laboratory and pot experiments. The laboratory experiment included the iso-osmotic potentials of $-0.275,-0.4$, and $-0.47 \mathrm{MPa}$ of polyethylene glycol (PEG, as a drought factor) and wastewater. In addition, the pot experiment included a wastewater factor (i.e., tap water, $100 \%$ refined wastewater, $50 \%$ refined wastewater $+50 \%$ non-refined wastewater, and $100 \%$ non-refined wastewater) and a drought factor (i.e., an irrigation interval of two and three days as normal and drought conditions, respectively). The results demonstrated that the drought related to PEG did not reduce seed germination while wastewater decreased seed germination. Further, an osmotic potential of -0.47 MPa resulted in the highest and lowest radicle length in both wastewater and PEG, respectively. The results also revealed that caulicle length and seed vigour were decreased by PEG as the osmotic potential increased while no significant difference was observed between wastewater treatments and distilled water (control). Based on the results, an irrigation interval of 3 days with $100 \%$ non-refined wastewater produced the highest chlorophyll content and $100 \%$ refined and $100 \%$ non-refined wastewater produced a larger leaf area compared to the control. Furthermore, drought with wastewater application increased specific leaf weight whereas it reduced the total biomass compared to control (i.e., tap water with an irrigation interval of 2 days), except for $100 \%$ non-refined wastewater. Therefore, wastewater application compensates for the adverse effect of drought due to nutrient addition.
\end{abstract}

Keywords: chlorophyll, drought, refined wastewater, seed vigour

\section{INTRODUCTION}

Drought is considered to be one of the most important factors which limits crop production across the globe. Agricultural production should be increased to meet global population demands (Tilman et al., 2011). Irrigation is regarded as one of the methods which effectively increases crop production while water use efficiency typically remains stable under different water amounts (Curt et al., 1995). According to Mustafa Tahir et al. (2014), shortening the irrigation interval at the critical periods of growth can lead to an increase in plant height and forage yield for oats.

Chlorophyll concentration is a key factor in photosynthesis rate (Ghosh et al., 2004), which increases under drought since leaf area reduces and the leaf becomes thicker, leading to an increase in chlorophyll concentration (Barraclough and Kate, 2001).

Wastewater (e.g., domestic and industrial types) can be used for crop irrigation. In addition, it has been found to increase plant height and biomass in wheat (Pandey and Singh, 2015). According to Ashraf and Ali (2007), seed germination is one of the sensitive stages in plant growth and, as an index of plant sensitivity to contamination, has attracted the attention of different studies. Wastewater contains salts and heavy metals. Li et al. (2005) reported that an increase in heavy metal concentration caused a decline in seed germination percentage. The highest wheat seed germination was recorded at $25 \%$ effluent concentration when compared to a variety of other concentrations (e.g., $0 \%, 25 \%, 50 \%, 75 \%$, and $100 \%$ ) of effluents from a textile and sugar factory (Nandal et al.,
2017). Seedling root and shoot growth decreased relative to a control when applying effluents from a pharmaceutical and battery industry at various irrigation intervals (Raju et al., 2015).

However, various studies have reported different adverse effects of salinity and drought. Both salinity and drought reduce coleoptile and root length, as well as the fresh and dry weight of the root and coleoptiles in wheat (Jovovic et al., 2018). The drought and salinity in these studies resulted from polyethylene glycol and $\mathrm{NaCl}$, respectively, and had no significant effect on seed germination percentage, germination rate, or seedling shoot and root weight in wheat, compared to the control (Mohammadi and Dargahi, 2015). Farmers may use wastewater for irrigation, in refined or non-refined form, from different sources including a domestic source. Further, physical and chemical processes may be utilized for treating the wastewater (Mlakar et al., 2017). The application of nonrefined wastewater for irrigation can inhibit plant growth through cell division, due to sticky and lagging chromosomes (Sik et al., 2009), and irrigating plants with non-refined wastewater may cause disease if directly applied by a person. Conversely, several other studies have indicated that nonrefined wastewater can promote plant growth (Moradi et al., 2016; Khaleel et al., 2013).

It is not clear whether refined wastewater can have the same promoting effect as non-refined wastewater. Furthermore, wastewater refinement is a costly process and its efficiency needs evaluation. Therefore, the current study sought to compare physical, chemical, and biological traits of refined and non-refined wastewater and their effects on seed germination and early plant growth in wheat under drought.

*Corresponding author, email: heidari1383@gmail.com

Received 18 March 2018; accepted in revised form 20 September 2019 


\section{MATERIALS AND METHODS}

\section{Laboratory experiment}

A laboratory experiment was conducted at Physiology Laboratory, the College of Agricultural Science and Engineering, Razi University, during 2014. Based on the aim of the study, the treatments encompassed the iso-osmotic potentials of -0.275 , -0.4 , and $-0.47 \mathrm{MPa}$ (equal to $100 \%$ refined wastewater, $50 \%$ refined wastewater $+50 \%$ non-refined wastewater, and $100 \%$ non-refined wastewater, respectively), of polyethylene glycol (PEG, as a drought factor) and refined or non-refined wastewater. Table 1 demonstrates some of the parameters of refined and nonrefined wastewater. PEG solutions were prepared according to Michel and Kaufmann's formula (1973):

$Y_{s}=-\left(1.18 \times 10^{-2}\right) C-\left(1.18 \times 10^{-4}\right) C^{2}+\left(2.67 \times 10^{-4}\right) C T+\left(8.39 \times 10^{-7}\right) C^{2} T$

where: $Y, C$, and $T$ demonstrate the osmotic potential, the concentration of PEG in g. $\mathrm{kg}^{-1} \mathrm{H}_{2} \mathrm{O}$, and the temperature in degrees Celsius, respectively. The osmotic potentials of wastewater were measured using an osmometer and distilled water was utilized as a control. Therefore, the experiment comprised 7 treatments (i.e., one control and $-0.275,-0.4$, and $-0.47 \mathrm{MPa}$ of polyethylene glycol and wastewater). The study was conducted as a completely randomized design with 3 replications. Ghareso is a river in Kermanshah and the wastewaters from industrial and domestic sources are discharged into this river. Additionally, a wastewater treatment plant exists in Kermanshah to purify part of the effluents. In general, the purification process occurs in 3 steps: physical purification, which encompasses the construction of overflow, screens, the initial sedimentation ponds, the secondary sedimentation ponds, and the pump house of the sludge; chemical purification, which involves activated sludge and chlorination pools; and, finally, biological treatment, which involves biological reactors (Iran's Environmental Health, 2019). Wastewater samples were collected from Kermanshah wastewater treatment plant with an output of $60000 \mathrm{~m}^{3} \cdot \mathrm{day}^{-1}$ (Ghamarnia et al., 2014), which serves 400000 persons.

To assess the effect of wastewater and drought on seed germination, the seeds of wheat (Triticum aestivum cv. Sirwan) were placed on filter paper in Petri dishes and then $6 \mathrm{~mL}$ of the prepared solution was added to each Petri dish. Next, these dishes were kept in a germinator for a week, after which several parameters were measured: seed germination percentage, caulicle length, radicle length, radicle to caulicle ratio, and seed vigour. Seed vigour was calculated by Heidari’s (2013) equation.

\section{Pot experiment}

An outdoor pot experiment was conducted at the College of Agricultural Science and Engineering, Razi University, in 2014. The experiment was conducted as a factorial arrangement based on a randomized complete block design with 3 replicates. One factor was wastewater (i.e., tap water, $100 \%$ refined wastewater, $50 \%$ refined wastewater $+50 \%$ non-refined wastewater, and $100 \%$ non-refined wastewater). The other factor included irrigation intervals ( 2 and 3 days) which were determined by a pre-experiment. In the pre-experiment, the irrigation intervals of 2 and 3 days were determined as well-watered and drought treatments, respectively, based on soil factors and plant symptoms. At each irrigation event, the soil surface was gradually watered to ensure the soil was totally wet. Then, watering was stopped when the pot soil started to drain and the seeds of the wheat (Triticum aestivum $\mathrm{cv}$. Sirwan) were sown in pots $(7 \mathrm{~cm}$ in diameter and $7.5 \mathrm{~cm}$ in height) filled by field soil. The experiment lasted 21 days, after which related parameters were estimated: leaf chlorophyll content, plant height, leaf area, stem fresh and dry weight, leaf fresh and dry weight, leaf to stem ratio, total biomass, and specific leaf weight. Specific leaf weight was calculated by dividing leaf dry weight by leaf area. A SPAD (soil plant analytical development) device was used to determine the index of leaf chlorophyll (Bail et al., 2005). Finally, leaf and stem samples were dried in an oven at $70^{\circ} \mathrm{C}$ for $24 \mathrm{~h}$ in order to calculate their dry weight.

\section{Data analysis}

Data were analysed by SAS software and the means were compared by applying Duncan's multiple range test at a probability level of $5 \%$.

\section{RESULTS}

\section{Water quality}

The effluent quality was improved by the wastewater treatment plant (Table 1). For example, heavy metals, as well as some essential nutrients for plant growth, such as nitrogen and

Table 1. Non-refined and refined wastewater parameters (Dindarlou and Dastourani, 2018; Ghamarnia et al., 2014)

\begin{tabular}{|c|c|c|}
\hline Parameter & $\begin{array}{l}\text { Non-refined } \\
\text { wastewater }\end{array}$ & $\begin{array}{c}\text { Refined } \\
\text { wastewater }\end{array}$ \\
\hline $\mathrm{NO}^{-}\left(\mathrm{mg}^{-\mathrm{L}^{-1}}\right)$ & 70 & 30 \\
\hline $\mathrm{PO}^{-(3)}\left(\mathrm{mg} \cdot \mathrm{L}^{-1}\right)$ & 15.6 & 4.3 \\
\hline $\mathrm{K}\left(\mathrm{mg} \cdot \mathrm{L}^{-1}\right)$ & 8.6 & 8.7 \\
\hline $\mathrm{Na}\left(\mathrm{mg} \cdot \mathrm{L}^{-1}\right)$ & 45 & 23 \\
\hline $\mathrm{Ca}\left(\mathrm{mg} \cdot \mathrm{L}^{-1}\right)$ & 277.9 & 144.2 \\
\hline $\mathrm{Mg}\left(\mathrm{mg} \cdot \mathrm{L}^{-1}\right)$ & 98.4 & 48.6 \\
\hline $\mathrm{K}\left(\mathrm{mg} \cdot \mathrm{L}^{-1}\right)$ & 8.6 & 4.3 \\
\hline $\mathrm{Al}\left(\mathrm{mg} \cdot \mathrm{L}^{-1}\right)$ & 6.3 & 5.3 \\
\hline $\mathrm{Cl}\left(\mathrm{mg} \cdot \mathrm{L}^{-1}\right)$ & 63.5 & 39.28 \\
\hline$B\left(m g \cdot L^{-1}\right)$ & 0.5 & 0.04 \\
\hline $\mathrm{Hg}\left(\mathrm{mg} \cdot \mathrm{L}^{-1}\right)$ & 0.08 & 0.009 \\
\hline $\mathrm{Fe}\left(\mathrm{mg} \cdot \mathrm{L}^{-1}\right)$ & 10.5 & 22.11 \\
\hline $\mathrm{Cu}\left(\mathrm{mg} \cdot \mathrm{L}^{-1}\right)$ & 0.05 & 0.01 \\
\hline $\mathrm{Zn}\left(\mathrm{mg} \cdot \mathrm{L}^{-1}\right)$ & 1.3 & 0.1 \\
\hline $\mathrm{Cd}\left(\mathrm{mg} \cdot \mathrm{L}^{-1}\right)$ & 0.09 & 0.05 \\
\hline $\mathrm{Ni}\left(\mathrm{mg} \cdot \mathrm{L}^{-1}\right)$ & 0.06 & 0.03 \\
\hline $\mathrm{Cr}\left(\mathrm{mg} \cdot \mathrm{L}^{-1}\right)$ & 0.07 & 0.02 \\
\hline $\mathrm{Pb}\left(\mathrm{mg} \cdot \mathrm{L}^{-1}\right)$ & 0.09 & 0.01 \\
\hline $\mathrm{Mn}\left(\mathrm{mg} \cdot \mathrm{L}^{-1}\right)$ & 3.2 & 4.3 \\
\hline $\mathrm{Co}\left(\mathrm{mg} \cdot \mathrm{L}^{-1}\right)$ & 0.05 & 0.04 \\
\hline As $\left(\mathrm{mg} \cdot \mathrm{L}^{-1}\right)$ & 0.07 & 0.02 \\
\hline Se $\left(m g \cdot L^{-1}\right)$ & 0.1 & 0.04 \\
\hline Total suspended solids $\left(\mathrm{mg} \cdot \mathrm{L}^{-1}\right)$ & 83.8 & 20.4 \\
\hline Total dissolved solids $\left(\mathrm{mg} \cdot \mathrm{L}^{-1}\right)$ & 801.7 & 619.4 \\
\hline Total organic carbon $\left(\mathrm{mg} \cdot \mathrm{L}^{-1}\right)$ & 62.4 & 19.3 \\
\hline Total hardness $\left(\mathrm{mg} \cdot \mathrm{L}^{-1}\right)$ & 1104.75 & 563.9 \\
\hline Sodium adsorption ratio & 3.28 & 2.67 \\
\hline Turbidity (NTU) & 69.6 & 39.4 \\
\hline$E C\left(d s \cdot m^{-1}\right)$ & 0.429 & 0.76 \\
\hline $\mathrm{pH}$ & 6.33 & 7.9 \\
\hline Total coliform (MPN $100 \mathrm{~mL}^{-1}$ ) & 1500 & 95 \\
\hline
\end{tabular}

NTU: nephelometric turbidity units; EC: electrical conductivity 

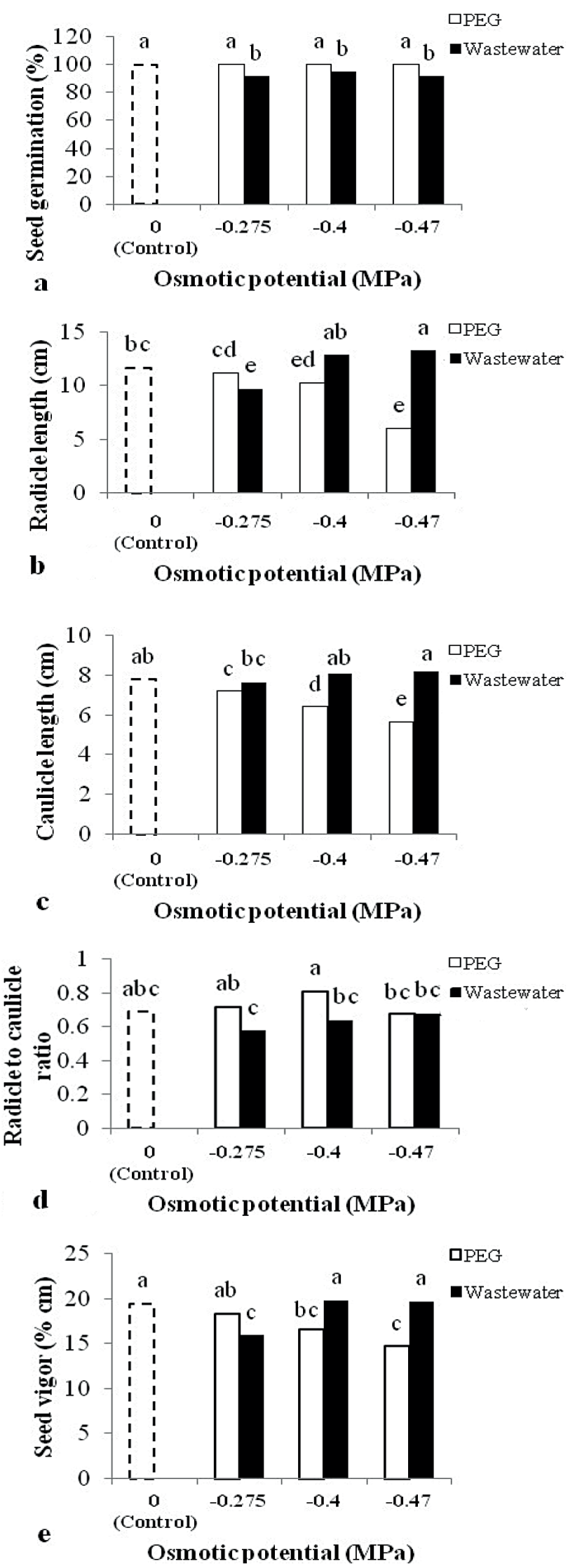

Figure 1. The effect of the iso-osmotic potentials of PEG and wastewater on seed germination traits in wheat. Means with the same letter represent no significant differences $(P<0.05)$. phosphorus, were reduced by wastewater treatment. Fe increase could be attributed to $\mathrm{FeCl}_{3}$ for coagulation. $\mathrm{Mn}$ increase could be due to the lack of subsurface oxygen. $\mathrm{pH}$ increase could be attributed to liming.

\section{Laboratory experiment}

Figure 1 illustrates the influence of polyethylene glycol (PEG) iso-osmotic potentials and wastewater on the seed germination traits of wheat. Drought related to PEG fails to reduce seed germination while wastewater decreases it (Fig. 1a). Further, germination reduction by wastewater is initiated by the lowest osmotic potential. The osmotic potential of $-0.47 \mathrm{MPa}$ for the wastewater and PEG resulted in the highest and lowest radicle length, respectively (Fig. 1b). An increase in osmotic potential leads to a decrease in the caulicle length with PEG, whereas no significant difference is observed between wastewater treatments and distilled water as control (Fig. 1c). With regard to the radicle to caulicle ratio, there is also no significant difference between wastewater treatments and distilled water (Fig. 1d). Furthermore, seed vigour decreases with PEG through increasing the osmotic potential, while wastewater treatments and distilled water demonstrate no significant difference in terms of seed vigour (Fig. 1e).

\section{Pot experiment}

The effect of irrigation interval and wastewater on early growth traits in wheat is displayed in Fig. 2. The irrigation interval of 3 days with $100 \%$ non-refined wastewater produces the highest chlorophyll content. More precisely, drought reduces leaf area while increasing leaf thickness (specific leaf weight), leading to an increase in chlorophyll concentration which is confirmed by the results of the current experiment (Fig. 2a). Under the irrigation interval of 2 days, leaf fresh weight increases for all wastewater treatments whereas under the irrigation interval of 3 days, only $100 \%$ non-refined wastewater results in an increase in leaf fresh weight (Fig. 2b). Drought reduces leaf dry weight (Fig. 2c). Additionally, 100\% refined wastewater produces the highest stem dry weight. A remarkable reduction of some nutrients while improving some physiochemical properties of wastewater (e.g., electrical conductivity) in $100 \%$ refined wastewater results in increasing the stem dry weight (Fig. 2d). In addition, $100 \%$ refined wastewater with an irrigation interval of 2 days reveals higher plant height compared to the control, namely, tap water with an irrigation interval of 2 days. By increasing the irrigation interval, the height of the plant irrigated by $100 \%$ nonrefined wastewater shows no reduction (Fig. 2e), which is likely due to the positive effect of wastewater on plant growth. Further, 100\% refined and 100\% non-refined wastewater produce a higher leaf area compared to the control (Fig. 2f). The lowest and highest leaf to stem ratio, among the treatments, is observed for $100 \%$ refined wastewater with an irrigation interval of 2 and 3 days, respectively (Fig. 2g). On the other hand, drought increases leaf to stem ratio under $100 \%$ refined wastewater. This suggests that stem elongation initiation is postponed by drought. Additionally, drought with wastewater application leads to an increase in specific leaf weight compared to the control (Fig. 2h), and finally, drought reduces total biomass compared to the control, except in the case of $100 \%$ wastewater (Fig. 2i). 

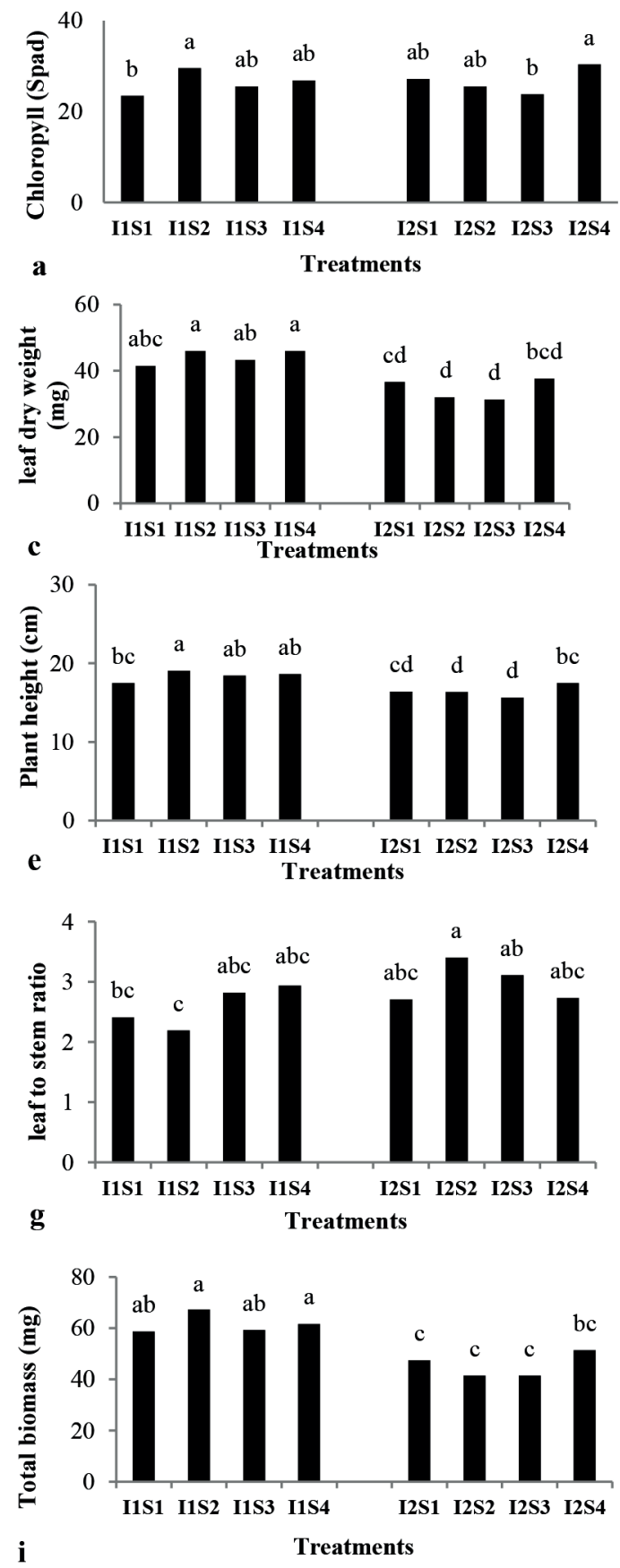
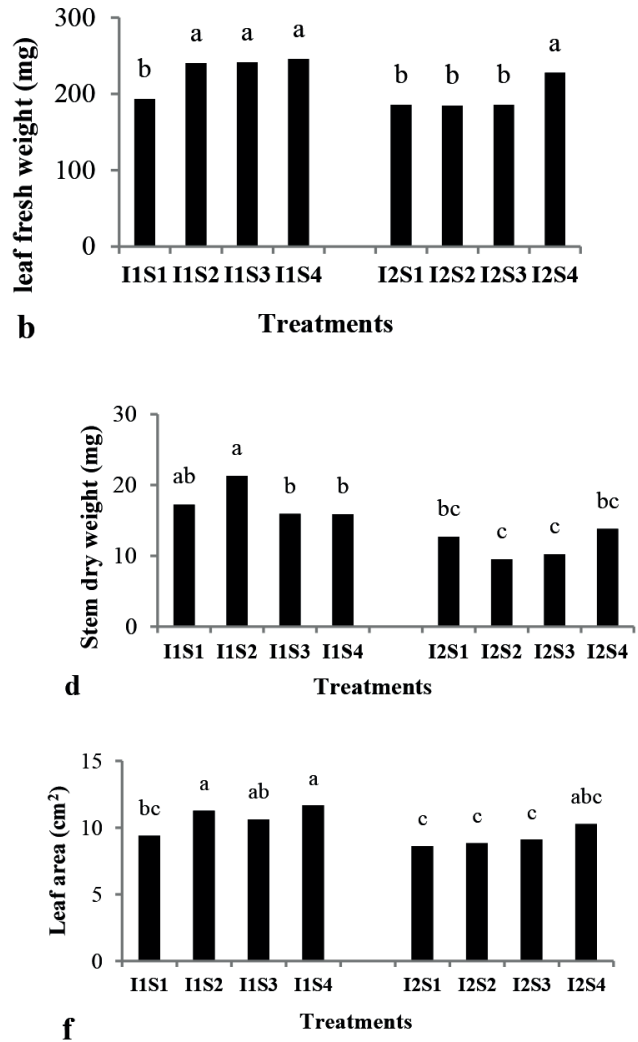

f

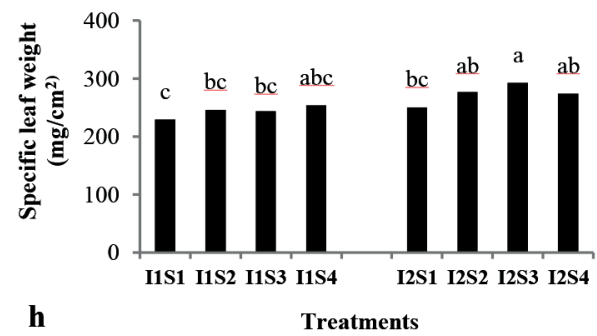

Figure 2. The effect of irrigation interval and wastewater on early growth traits in wheat. Note: S1, S2, S3, and S4 represent tap water, $100 \%$ refined wastewater, $50 \%$ refined wastewater $+50 \%$ non-refined wastewater, and $100 \%$ non-refined wastewater, respectively. In addition, I1 and 12 are the irrigation intervals of 2 and 3 days. Means with the same letter indicate no significant differences $(P<0.05)$.

\section{DISCUSSION}

\section{Laboratory experiment}

The reduction in seed germination by wastewater can be attributed to salinity and heavy metal stresses, which is confirmed by the data in Table 1. Further, higher electrical conductivity and some inhibiting elements, including $\mathrm{Na}$, in the wastewater are the main reasons for such a reduction in seed germination. Apparently, salinity stress had a negative effect on germination while some nutrients promoted radicle and caulicle length after germination in the present study. However, these nutrients demonstrated their effect only at high concentration. The adverse effect of osmotic potential was compensated for by the positive effect of wastewater due to nutrients (Li et al., 2005). Raju et al. (2015) also reported a decline in wheat seed germination due to effluent from a pharmaceutical and battery industry, which is in line with the results of the current study. Furthermore, some other studies found that seed priming by sodium compounds such as sodium silicate (Hameed et al., 2013) and sodium nitroprusside (Ali et al., 2017) enhance seedling root and shoot growth in wheat 
due to a reduction in the oxidative stress of salinity. This corroborates the results of the present study. Contrary to the results of the current study, Sayar et al. (2010) concluded that drought stress resulting from polyethylene glycol (PEG) had a higher adverse effect on germination percentage in wheat compared to NaCl-related salinity. Additionally, PEG-induced drought stress had an even more negative effect on radicle to caulicle ratio compared to wastewater (Fig. 1d). Essential nutrients available in wastewater reduced the negative effects of drought. Saidi et al. (2010) reported that root weight increases in wheat seedlings under increasing drought. Seed treated with wastewater represented higher seed vigour under the osmotic potential of -0.4 and $-0.47 \mathrm{MPa}$, compared to the seed treated with PEG (Fig. 1e). The results of another study indicated that $\mathrm{NaCl}$ had a more adverse effect on germination compared to drought (Al-taisan, 2010) while other studies have reported that drought had a more adverse effect on germination compared to $\mathrm{NaCl}$ (e.g., Okcu et al., 2005; Rahimi et al., 2006).

\section{Pot experiment}

Heidari et al. (2011) found an increase in the chlorophyll content of water-stressed plants while Abdalla and El-khoshiban (2007) reported that drought reduced the chlorophyll content. This contradiction can be attributed to stress severity. In other words, chlorophyll is destroyed under severe drought which leads to a decrease in its content. In this respect, the effect of wastewater should be considered as well. Wastewater contains essential nutrients, including nitrogen, for plant growth and chlorophyll formation, and chlorophyll content, as one of source strength components, is affected by wastewater (Ghosh et al., 2004). In addition, $100 \%$ non-refined wastewater contains more nutrients than tap water and refined wastewater (Table 1). Leaf fresh weight mainly relies on leaf moisture and its trend indicates that wastewater salts may be absorbed by plant tissues. Further, salts accumulate water, thus the leaf becomes succulent (Sen and Rajpurohit, 2012) and drought reduces leaf dry weight. In the present study, the comparison of leaf dry and fresh weight revealed that wastewater increased leaf moisture (Fig. 2). According to Alyemeny (1998), a reduction in leaf biomass helps the plant to tolerate water deficit, and plant height reduction as a result of drought is considered as an adaptation response of plants in order to reduce transpiration (Karam et al., 2003). Furthermore, drought decreases cell size and internode length (Ludlow et al., 1990). However, based on the results of the current study, drought did not reduce leaf area for the $100 \%$ non-refined wastewater treatment (Fig. 2). A larger amount of nutrients such as nitrogen and phosphorus in $100 \%$ non-refined wastewater plays a role in chlorophyll production and increasing leaf area, compared to refined wastewater. Additionally, drought diminishes cell elongation and division, and thus reduces leaf area. Other studies, including Karam et al. (2003), have reported leaf area reduction due to drought as well. In addition, the results of the present study confirm that drought reduces the leaf area and increases the leaf thickness, leading to an increase in specific leaf weight (Fig. 2). The results further indicate that wastewater can promote plant growth by increasing the leaf thickness in order to capture more radiant energy. Water deficit leads to various morpho-physiological changes in the plants. For example, leaf growth is inhibited first, before photosynthesis and respiration, when there is a reduction in water potential, and soil water deficit reduces xylem sap movement toward the leaves (Liptay et al., 1998).

\section{CONCLUSIONS}

In general, an osmotic potential of $-0.47 \mathrm{MPa}$ of wastewater, resulted in the lowest seed germination percentage. Further, wastewater at low water potential failed to reduce seed germination traits such as seed vigour, while using polyethylene glycol to create a low osmotic potential decreased these traits. It is likely that the positive physiochemical properties of wastewater, including nitrogen content, acted to promote plant growth. Furthermore, plants irrigated with $100 \%$ refined wastewater under the well-watered condition produced the highest total biomass, since $100 \%$ refined wastewater contained growth-promoting ingredients such as nitrogen and phosphorus. Based on the results, drought reduced different growth parameters such as leaf and stem dry weight whereas wastewater application compensated for the negative effect of drought. Finally, drought decreased total biomass compared to control, except in the case of the $100 \%$ wastewater treatments. Therefore, irrigation of wheat with wastewater is recommended after germination instead of at the germination stage, and irrigation with refined wastewater can promote plant growth.

\section{REFERENCES}

ABDALLA MM and EL-KHOSHIBAN NH (2007) The influence of water stress on growth, relative water content, photosynthetic pigments, some metabolic and hormonal contents of two Triticium aestivum cultivars. J. Appl. Sci. Res. 3 (12) 2062-2074.

ALI Q, DAUD MK, HAIDER MZ, ALI S, RIZWAN M, ASLAM N, NOMAN A, IQBAL N, SHAHZAD F, DEEBA F, ALI I and ZHU SJ (2017) Seed priming by sodium nitroprusside improves salt tolerance in wheat (Triticum aestivum L.) by enhancing physiological and biochemical parameters. Plant Physiol. Biochem. 119 50-58. https://doi.org/10.1016/j.plaphy.2017.08.010

AL-TAISAN WA (2010) Comparative effects of drought and salt stress on germination and seedling growth of Pennisetum divisum (Gmel.) Hener. Am. J. Appl. Sci. 7 640-646. https://doi.org/10.3844/ ajassp.2010.640.646

ALYEMENY MN (1998) The effect of drought on growth and dry matter allocation in seedling of Vigna ambacensis L. J. King Saud Univ. 10 41-51.

ASHRAF R and ALI TA (2007) Effect of heavy metals on soil microbial community and mung beans seed germination. Pak. J. Bot. 39 629-636.

BAIL ML, JEUFFROY MH, BOUCHARD C and BARBORTIN A (2005) Is it possible to forecast the grain quality and yield of different varieties of winter wheat from Minolta SPAD Meter measurement? Eur. J. Agron. 23 379. https://doi.org/10.1016/j. eja.2005.02.003

BARRACLOUGH PB and KATE J (2001) Effect of water stress on chlorophyll meter reading in wheat. Plant Nutr. 92 722-723. https:// doi.org/10.1007/0-306-47624-X_350

CURT, MD, FERNANDEZ J and MARTINENZ M (1995) Productivity and water use efficiency of sweet sorghum (Sorghum bicolor (L.) moench) "keller" in relation to water regime. Biomass Bioenerg. 8 401-409. https://doi.org/10.1016/0961-9534(95)00036-4

DINDARLOU A and DASTOURANI M (2018) Investigation of the efficiency of sewage treatment using activated sludge method to supply water for reuse in agricultural irrigation (case study: Kermanshah sewage treatment plant). J. Water Sustainable Dev. 4 (2) 31-40.

GHAMARNIA H, MIRZAEI H and BROOUN SH (2014) Assessment of water quality in Garehsoo River and Kermanshah Sewerage Treatment Refinery to determine its allowable uses in accordance with national and international standards. In: The $7^{\text {th }}$ National Conference and Exhibition on Environmental Engineering, 8 December 2014, University of Tehran, Tehran.

GHOSH PK, AJAY KK, BANDYOPADYAY MC, MANNA KG, 
MANDAL AK and HATI KM (2004) Comparative effectiveness of cattle manure, poultry manure, phosphocompost and fertilizerNPK on three cropping systems in vertisols of semi-arid tropics, dry matter yield, nodulation, chlorophyll content and enzyme activity. Bioresour. Technol. 95 85-93. https://doi.org/10.1016/j. biortech.2004.02.012

HAMEED A, SHEIKH MA, JAMI A and BASRA SMA (2013) Seed priming with sodium silicate enhances seed germination and seedling growth in wheat (Triticum aestivum L.) under water deficit stress induced by polyethylene glycol. Pak. J. Life Soc. Sci. 11 (1) 19-24.

HEIDARI H (2013) Effect of irrigation with contaminated water by cloth detergent on seed germination traits and early growth of sunflower (Helianthus annuus L.). Not. Sci. Biol. 5 1-4. https://doi. org/10.15835/nsb519003

HEIDARI H, JAHANSOOZ MR, YUNUSA I, HOSSEINI SMB, CHAICHI MR and JAFARI AA (2011) Effect of alternate irrigation on root-divided Foxtail millet (Setaria italica). Aust. J. Crop Sci. 5 205-213.

Iran's Environmental Health (2019) Kermanshah wastewater treatment plant. URL: http://www.environmentalhealth.ir/836 (Accessed 21 January 2019).

JOVOVIC M, TUNGUZ V, MIROSAVLJEVIĆ M and PRŽULJ N (2018) Effect of salinity and drought stress on germination and early seedlings growth of bread wheat (Triticum aestivum L.). Genetika 50 (1) 285-298. https://doi.org/10.2298/GENSR1801285J

KARAM F, BREIDY J, STEPHAN C and ROUPHAEL J (2003) Evapotranspiration, yield and water use efficiency of drip irrigated corn in the Beka Valley of Lebanon. Agr. Water Manage. 63 125137. https://doi.org/10.1016/S0378-3774(03)00179-3

KHALEEL R, ISMAIL N and IBRAHIM H (2013) The impact of wastewater treatments on seed germination and biochemical parameter of Abelmoschus esculentus L. Procedia - Soc. Behav. Sci. 91 453-460. https://doi.org/10.1016/j.sbspro.2013.08.443

LI W, KHAN MA, YAMAGUCHI S and KAMIYA Y (2005) Effects of heavy metals on seed germination and early seedling growth of Arabidopsis thaliana. Plant Growth Regul. 46 45-50. https://doi. org/10.1007/s10725-005-6324-2

LIPTAY A, SIKKEMA P and FONTENO W (1998) Transplant growth control through water deficit stress-A Review. HortTechnology 8 (4) https://doi.org/10.21273/HORTTECH.8.4.540

LUDLOW MM and MUCHOW RC (1990) A critical evaluation of traits for improving crops yields in water limited environments. Agron. J. 69 78. https://doi.org/10.1016/S0065-2113(08)60477-0

MICHEL BE and KAUFMANN MR (1973) The osmotic potential of polyethylene glycol 6000. Plant Physiol. 51 914-916. https://doi. org/10.1104/pp.51.5.914

MLAKAR M, LEVSTEK M and STRAZAR M (2017) Physicochemical treatment of liquid waste on an industrial plant for electrocoagulation. Water Sci. Technol. 76 (7-8) 2188-2194. https:// doi.org/10.2166/wst.2017.390

MOHAMMADI M and DARGAHI F (2015) The wheat response to drought and salinity stresses. Cumhuriyet Univ. Faculty Sci. Sci. J. 36 (3) 1695-1700.

MORADI S, HEIDARI H, SAEIDI M and NOSRATTI I (2016) Effect of sewage-contaminated water on seed production, heavy metals accumulation and seedling emergence in oat. Glob. Nest J. 18 (2) 329-338. https://doi.org/10.30955/gnj.001838

MUSTAFA TAHIR GH, HAQ A, KHALIQ T, REHMAN M and HUSSAIN S (2014) Effect of different irrigation levels on yield and forage quality of oat (Avena sativa). Appl. Sci. Rep. 3 (1) 42-46. https://doi.org/10.15192/PSCP.ASR.2014.3.1.4246

NANDAL M, YADAY JP and RASTOGI M (2017) Effect of industrial effluents on mineral uptake of two Rabi crops (Triticum aestivum and Raphanus sativus). Nat. Environ. Pollut. Technol. 16 (2) 541-544.

OKCU G, KAYA MD and ATAK M (2005) Effects of salt and drought stresses on germination and seedling growth of pea (Pisum sativum L.). Turk. J. Agric. For. 29 237-242.

PANDEY R and SINGH J (2015) Effect of industrial wastewater irrigation on productivity of wheat crop. Int. J. Environ. Sci. 6 (3) 402-409.

RAHIMI A, JAHANSOZ MR, RAHIMIAN MASHHADI H, POSTINI $\mathrm{K}$ and SHARIFZADEH F (2006) Effect of iso-osmotic salt and water stress on germination and seedling growth of two Plantago species. Pak. J. Biol. Sci. 9 2812-2817. https://doi.org/10.3923/ pjbs.2006.2812.2817

RAJU K, VISHNUVARDHAN V and DAMODHARAM T (2015) Industrial effluents effect on seedling growth of rice and wheat (Oryza sativa L. and Triticum vulgare L.). Int. J. Recent. Sci. Res. 6 (7) 4935-4939.

SAIDI A, OOKAWA T and HIRASAWA T (2010) Responses of root growth to moderate soil water deficit in wheat seedlings. Plant Prod. Sci. 13 (3) 261-268. https://doi.org/10.1626/pps.13.261

SAYAR R BCHINIH MOSBAHI M and KHEMIRA H (2010) Response of durum wheat (Triticum durum Desf.) growth to salt and drought stresses. Czech J. Genet. Plant Breed. 46 (2) 54-63. https://doi. org/10.17221/85/2009-CJGPB

SEN DN and RAJPUROHIT KS (2012) Contributions to the ecology of halophytes. Springer, The Netherlands. 272 pp.

SIK L, ACAR O and AKI C (2009) Genotoxic effects of industrial wastewater on Allium cepa L. Afr. J. Biotechnol. 8 (9) 1919-1923.

TILMAN D, BALZER C, HILL J and BEFORT BL (2011) From the Cover: Global food demand and the sustainable intensification of agriculture. Proc. Natl. Acad. Sci. 108 20260-20264. https://doi. org/10.1073/pnas.1116437108 